\title{
PHOSPHORUS REQUIREMENTS BY MAIZE VARIETIES IN DIFFERENT SOIL TYPES OF WESTERN KENYA
}

\author{
C.J. WASONGA, D.O. SIGUNGA ${ }^{1}$ and A.O. MUSANDU ${ }^{2}$ \\ Cornell University, Department of Horticulture, 163 Plant Science Building, Ithaca, NY 14853 USA \\ ${ }^{1}$ Maseno University, Department of Horticulture, P.O. Private Bag, Maseno, Kenya \\ ${ }^{2}$ Egerton University, Department of Crop and Soil Sciences, P. O. Box 536 Njoro, Kenya
}

(Received 13 February, 2008; 30 May, 2008)

\begin{abstract}
Phosphorus and nitrogen deficiencies limit production of maize (Zea mays L.) in many soils of western Kenya. Considerable amount of work has been done on $\mathrm{N}$ nutrition of maize in the region. There is, however, paucity of information on which to base fertiliser $P$ recommendations for increased maize production considering potential differences in responses due to varieties, soil type, and climate. External and internal $\mathrm{P}$ requirements, and $\mathrm{P}$ utilisation efficiencies of two open pollinated varieties (Ababari and Oking') and one hybrid (H513) were examined at four P-deficient on-farm sites (2 Ferric Alisol, 1 Haplic Ferralsol, and 1Ferric Acrisol) in western Kenya. The varieties were grown under $\mathrm{P}$ fertilisation rates of 13, 26, 39, $52 \mathrm{~kg} \mathrm{P} \mathrm{ha}^{-1}$ and a check (no $\mathrm{P}$ application). Maize performance varied with site, rate of $\mathrm{P}$ application, and variety. The highest grain yields (15\% moisture content) at the sites varied from 2,732 to 6,479 $\mathrm{kg} \mathrm{ha}^{-1}$ for Ababari, 2,350 to 5,835 $\mathrm{kg} \mathrm{ha}^{-1}$ for $\mathrm{H} 513$, and 2,299 to 4,459 $\mathrm{kg} \mathrm{ha}^{-1}$ for Oking'. Internal P requirements ranged from 7 to $24 \mathrm{~kg} \mathrm{P} \mathrm{ha}^{-1}$ for Ababari, 4 to $18 \mathrm{~kg} \mathrm{P} \mathrm{ha}^{-1}$ for Oking', and 5 to $18 \mathrm{~kg} \mathrm{P} \mathrm{ha}^{-1}$ for H513. Internal P requirements depended on both variety and

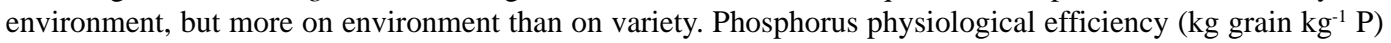
ranged from 111 to 314 for Ababari, 145 to 277 for Oking', and 127 to 390 for H513. Ababari performed as well as did H513, and the two were better than Oking'. Ababari is, therefore, recommended for the region since it is open pollinated and, hence, the peasant farmers do not have to buy the seeds every season. Row application of $\mathrm{P}$ is inappropriate in case determination of crop external $\mathrm{P}$ requirement is required.
\end{abstract}

Key Words: Ababari, internal P requirement, Oking', Zea mays

\section{RÉSUMÉ}

Les carences en phosphore et en azote limitent la production du maïs (Zea mays L.) dans beaucoup de sols de l'Ouest du Kenya. Un nombre considérable de travaux ont été effectués sur la nutrition en $\mathrm{N}$ du maïs dans la région. Il y a, cependant, manque d'information sur laquelle se référer pour émettre des récommandations en engrais $P$ pour la production accrue de maïs en considérant des différences potentielles dans les réponses dues aux variétés, aux types de sol, et au climat. Des exigences externes et internes en $\mathrm{P}$, et efficiences dans l'utilisation du P pour deux variétés en pollinisation naturelle (Ababari et Oking') et d'un hybride (H513) ont été examinées à quatre emplacements de champs caractérisés par des défficits en P (2 Alisol ferriques, 1 Haplic Ferralsol, et 1Acrisol Ferrique) à l'Ouest du Kenya. Les variétés ont été cultivées sous des taux de fertilisation en P de 13, 26, 39, 52 kg de $\mathrm{P} \mathrm{ha}^{-1}$ et d'un contrôle (sans application de P). La production du maïs a changé avec l'emplacement, le taux d'application de P, et la variété. Les rendements en grains les plus élevés (contenu d'humidité de 15\%) aux emplacements varient de 2.732 à $6.479 \mathrm{~kg} \mathrm{ha}^{-1}$ pour Ababari, 2.350 à $5.835 \mathrm{kgs} \mathrm{ha}^{-1}$ pour H513, et 2.299 à 4.459 $\mathrm{kg} \mathrm{ha}^{-1}$ pour Oking'. Les exigences internes en $\mathrm{P}$ se sont rangées de 7 à $24 \mathrm{~kg} \mathrm{P}^{\mathrm{P} a^{-1}}$ pour Ababari, 4 à $18 \mathrm{~kg} \mathrm{P}$

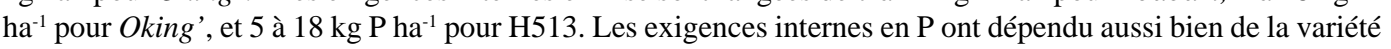
que de l'environnement, mais plus de l'environnement que sur la variété. L'efficience physiologique du phos-

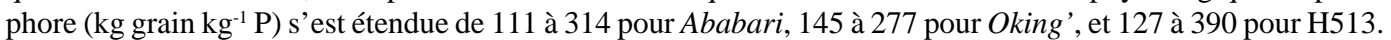


Ababari a produit autant que H513, et les deux étaient meilleures qu'Oking'. Ababari est par conséquent recommandée pour la région d'autant plus qu'elle est pollinisée naturellement et, ainsi, les agriculteurs ruraux n'auront plus à acheter les graines chaque saison. L'application du $\mathrm{P}$ en ligne de culture est inadéquate au cas où l'apport du P à la plante est exigé.

Mots Clés: Ababari, exigence d'apport du P, Oking', Zea mays

\section{INTRODUCTION}

Maize (Zea mays L.) is the staple food crop for majority of Kenyans. Both commercial farmers and smallholders grow the crop, but in most areas in Kenya production is constrained by low soil nitrogen and phosphorus availability (Sanchez, 2002; Bunemann, 2003; FAO, 2004). Phosphorus deficiency in many of the soils is largely due to low occurrence of P-containing minerals (Nyandat, 1981; Bunemann, 2003) and P-fixation (Van der Eijk, 1997). Continuous cropping without commensurate nutrient replenishment is reported to contribute to low P content of many soils (Smaling et al., 1997; Sanchez, 2002; Bunemann, 2003; FAO, 2004). This scenario is typical of the maize growing soils of western Kenya where smallholder farmers continuously grow the crop without adequate nutrients. Most of these smallholder farmers are resource poor and often grow open pollinated varieties in preference to hybrid maize due to high costs of hybrid seeds. Fertiliser use as a strategy for replenishing soils with limiting nutrients is a critical component in improving the productivity of maize in the region (FAO, 2004). However, there is need for guidelines to promote efficient fertiliser use in maize production with both economic and environmental perspectives duly considered (Keerthsinghe et al., 2003; Oenema and Pietrzak, 2002).

Substantial work has been done on $\mathrm{N}$ nutrition of maize in western Kenya (Njui and Musandu, 1999; Sanchez, 2002; Sigunga et al., 2002). With respect to $\mathrm{P}$, there is paucity of information on which to base fertiliser $\mathrm{P}$ recommendations for increased maize production, considering potential differences in $\mathrm{P}$ requirements by open pollinated varieties and hybrids grown in the different soil types. Some of the soil types associated with maize growing in the region are Ferralsols, Acrisols, Alisols, Nitisols and Luvisols in the uplands; and Vertisols, Gleysols and Planosols in the low-lying depressions (Jaetzold and Schmidt, 1982).

Maize varieties are known to vary in $P$ uptake and utilisation efficiencies, as well as in adaptability to different soil types (Nielsen and Barber, 1978; Walker and Raines, 1988; Duncan and Baligar, 1990; Horst et al., 1993; Machado et al., 1999). This implies that there are differences among maize varieties with respect to $P$ requirements. Hence, there is a need to quantify the differences.

Phosphorus demands by maize varieties can be viewed in terms of internal and external requirements. Internal $P$ requirement of a crop refers to the minimum uptake that is associated with a specified yield (usually $80 \%$ of the maximum yield); while external $P$ requirement refers to the maximum concentration of $\mathrm{P}$ in soil solutions equilibrated with soils associated with near maximum attainable yield (usually $80 \%$ of the maximum yield) for the crop (Fox, 1981; Hedley, 1995; Hue et al., 2000; Obaid-ur-Rehman et al., 2004).

This study quantified internal and external $\mathrm{P}$ requirements as well as $\mathrm{P}$ utilisation efficiency by open pollinated and hybrid maize varieties grown on some of the $P$ deficient soils in western Kenya.

\section{MATERIALS AND METHODS}

Experimental sites. Field experiments were carried out at 4 on-farm sites: Ayora, Wagai, Aboke and Ukwala located in Siaya District of western Kenya. The sites were selected to represent 4 different agro-ecological zones. Details of the experimental sites with respect to positions and climatic conditions are presented in Table 1. Data on potential evapotranspiration at the sites were obtained from ACT version 3.0 (Corbett et al., 2001). Soils at Ayora and Wagai 
were classified as Ferric Alisols, while those at levels, that is, 13, 26, 39, and $52 \mathrm{~kg} \mathrm{Pha}^{-1}$. A check Aboke and Ukwala were classified as Haplic (i.e., plot without P application) was included. Ferralsol and Ferric Acrisol (FAO-UNESCO, The maize varieties used were Oking' and 1997). Selected physical and chemical properties Ababari (open pollinated varieties) dominantly of the experimental soils are presented in Table 2. grown by farmers in the study area, and H513 (hybrid) recommended for the area. Oking' and Experimental procedure. The treatments Ababari were obtained from smallholder farmers comprised of 3 maize varieties and 4 fertiliser P in the region, while H513 was purchased from

TABLE 1. Summary of location and climate data of experimental sites

\begin{tabular}{|c|c|c|c|c|}
\hline \multirow[t]{2}{*}{ Parameter } & \multicolumn{4}{|c|}{ Site } \\
\hline & Ayora & Wagai & Aboke & Ukwala \\
\hline \multicolumn{5}{|l|}{ Position $^{\dagger}$} \\
\hline Longitude & $034.4023^{\circ}$ & $034.4220^{\circ}$ & $034.1649^{\circ}$ & $034.2009^{\circ}$ \\
\hline Latitude & $00.0530^{\circ}$ & $00.0566^{\circ}$ & $00.2468^{\circ}$ & $00.2043^{\circ}$ \\
\hline Altitude (m) & 1198 & 1202 & 1065 & 1043 \\
\hline \multicolumn{5}{|l|}{ Climate } \\
\hline Rainfall (mm) & 459 & 470 & 380 & 452 \\
\hline Rainy days ${ }^{\ddagger}$ & 60 & 61 & 35 & 39 \\
\hline Potential evapotranspiration (mm) & 477 & 477 & 476 & 492 \\
\hline
\end{tabular}

${ }^{\dagger}$ Site position details were obtained using a Global Positioning Tool, GPS 12XL (1998, Garmin, Olathe, USA)

${ }^{\ddagger}$ A rainy day was considered as one with $2 \mathrm{~mm}$ or more of rainfall

TABLE 2. Some chemical and physical properties of soils ( $0-30 \mathrm{~cm}$ depth) at the 4 sites

\begin{tabular}{|c|c|c|c|c|c|}
\hline \multirow[t]{2}{*}{ Parameter } & \multicolumn{4}{|c|}{ Site } & \multirow[t]{2}{*}{ Critical value $^{1}$} \\
\hline & Ayora & Wagai & Aboke & Ukwala & \\
\hline $\mathrm{pH}$ (water) & 5.1 & 4.8 & 5.4 & 5.5 & - \\
\hline $\mathrm{pH}\left(\mathrm{CaCl}_{2}\right)$ & 4.8 & 4.4 & 5.0 & 4.9 & - \\
\hline Organic Carbon (\%) & 1.5 & 0.9 & 0.7 & 0.6 & 0.5 \\
\hline \multicolumn{6}{|c|}{ Exchangeable cations $\left(\mathrm{cmol}_{\mathrm{c}} \mathrm{kg}^{-1}\right.$ soil) } \\
\hline Magnesium & 4.7 & 5.8 & 1.2 & 1.8 & 1.0 \\
\hline Potassium & 8.9 & 8.0 & 3.1 & 3.6 & 0.4 \\
\hline Calcium & 5.2 & 4.6 & 1.8 & 2.0 & 2.0 \\
\hline Exchangeable acidit (cmol $\mathrm{kg}^{-1}$ soil) & 14.6 & 9.2 & 3.0 & 2.8 & - \\
\hline Al saturation (\%) & 44.0 & 33.0 & 23.0 & 20.0 & $\left(e^{\prime \prime 30}\right)^{\star}$ \\
\hline CEC ( $\mathrm{cmol}_{\mathrm{c}} \mathrm{kg}^{-1}$ soil) & 38.7 & 39.0 & 16.0 & 18.5 & - \\
\hline Total P $\left(\mathrm{mg} \mathrm{kg}^{-1}\right)$ & 35.0 & 33.0 & 48.7 & 50.0 & - \\
\hline Available $\mathrm{P}\left(\mathrm{mg} \mathrm{kg}^{-1}\right)$ & 3.8 & 3.5 & 6.2 & 8.0 & 10 \\
\hline Texture & Sandy Loam & Sandy Loam & Sandy Loam & Sandy Loam & - \\
\hline
\end{tabular}

${ }^{1}$ Source: Hinga et al., 1980; Okalebo et al., 2002; *At this level Al is toxic to maize plant 
Kenya Seed Company, the leading governmentbacked seed company in the country. The 15 treatment combinations were factorially arranged in a randomised complete block design (RCBD) and replicated three times at each of the 4 experimental sites.

Both nitrogen and phosphate fertilisers were row applied at planting along furrows and mixed with soil to avoid direct contact with seed. Triple superphosphate (TSP) was used to supply P. Calcium ammonium nitrate (CAN) was applied to supply $\mathrm{N}$ at $80 \mathrm{~kg} \mathrm{ha}^{-1}$ to all plots to ensure that $\mathrm{N}$ did not constitute a constraint. The Furadan (carbofuran) pesticide was applied (5 $\mathrm{kg} \mathrm{ha}^{-1}$ ) with the seed at planting to protect the seeds against soil borne pests. Kombat, a permethrinebased commercial stock borer control dust was applied at a rate of $4 \mathrm{~kg} \mathrm{ha}^{-1}$ into the whorls of maize plants at 4 weeks after planting to protect the crop against damage by maize stalk borer (Busseola fusca).

Soil sample analysis. Composite soil samples, obtained from $0-30 \mathrm{~cm}$ depth were collected from each of the sites before land preparation and used to characterise the soils at the sites. At harvest, soil samples were collected from within rows (0$30 \mathrm{~cm}$ depth) in each of the experimental plots for analysis of soil solution $\mathrm{P}$ concentration values that were subsequently used in determination of external P requirements. Soil pH (water and 0.01 $M \mathrm{CaCl}_{2}$ ) analysed at 1:2.5 soil-solution ratio, was determined electrometrically (Van Lierop, 1990). Soil texture was determined by the hydrometer method (Gee and Bauder, 1986). Soils were analyzed for exchangeable acidity following extraction by $1 M$ potassium chloride and titration of the extract against sodium hydroxide solution following the procedure described by Okalebo et al. (2002).

Organic carbon was determined using Walkley-Black procedure (Nelson and Sommers, 1982). Organic carbon was determined following procedure described by Okalebo et al. (2002). Potassium was determined using flame spectrometer, while $\mathrm{Ca}$ and $\mathrm{Mg}$ were determined using Atomic Absorption Spectrophotometer (Okalebo et al., 2002).
Exchangeable acidity was determined following routine procedures (Anderson and Ingram, 1993; Okalebo et al., 2002).

In the determination of total P, $0.30 \mathrm{~g}$ of airdry was digested in $2.5 \mathrm{ml}$ of digestion mixture (salicylic acid, sulphuric acid, and selenium) until the digest became clear. The $\mathrm{pH}$ of the digest was adjusted by $6 \mathrm{M} \mathrm{NH}_{3}$ solution and then $1 \mathrm{M}$ $\mathrm{HNO}_{3}$ drop wise. Ammonium molybdate/ ammonium vanadate mixture $(5 \mathrm{ml})$ was added to the digest, the volume made to $50 \mathrm{ml}$ with distilled water and left to develop yellow colour; the P concentration was read from a colorimeter set at 400 nm (Okalebo et al., 2002). The initial soil physical and chemical properties at the experimental sites are presented in Table 2.

Plant sample analysis. At harvest (early August), above-ground portion of plants were harvested from the 3 middle rows in each plot. The harvested plants from the harvest area $(2.25 \mathrm{~m} \mathrm{x} 4.8 \mathrm{~m})$ in each plot were divided into stover (stalk and leaves), cob, and grains. The stover portion was chopped into small pieces, weighed and subsampled for dry matter determination. The cobs were similarly treated. The grain was weighed, and moisture content measured using moisture meter (Agromatic Mark II, Farmer Tronic, Denmark), and then sub-sampled for dry matter determination. Plant sub-samples for dry matter determination were oven-dried at $70^{\circ} \mathrm{C}$ in a ventilated oven to constant weight. The weights of oven-dry sub-samples were recorded and used to calculate total above-ground dry matter yields. Plant sub-samples were then fine ground for subsequent digestion and analysis for $\mathrm{P}$ content, using the procedure described above for total $\mathrm{P}$ in soil.

Calculation procedures and statistical analysis of data. Stand count, grain, cob, and stover weights were recorded for each of the treatments. Total dry matter yield, grain yield (at 15\% moisture content), and total $\mathrm{P}$ uptake were calculated using the following formulae:

Total dry matter yield (above-ground $)=($ GY + SY

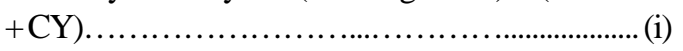


Grain yield (at 15\% moisture content) = GW x (100 - MCA)/(100 - MCD).

Total nutrient uptake $=($ NCG x GY $)+($ NCS x SY $)$

$+(\mathrm{NCC} x \mathrm{CY})$

Where:

GY, SY and CY are grain, stover, and cob dry matter yields, respectively; GW, MCA and MCD are fresh grain weight, moisture content of fresh grain and moisture content of grains at $15 \%$ moisture, respectively;

NCG, NCS and NCC are nutrient concentrations in grain, stover and cob, respectively, for the nutrient in question, which in this case was $P$.

Harvest Index $(\mathrm{HI})=\mathrm{GY} /$ Total dry matter

Phosphorus physiological efficiency $(\mathrm{PPE})=\mathrm{GY} /$ Total P uptake.

Internal $\mathrm{P}$ requirement $(\mathrm{IPR})=$ Minimum $\mathrm{P}$ uptake associated with $80 \%$ yield

The IPR is defined as the minimum $\mathrm{P}$ uptake that is associated with a specified yield (Fox, 1981; Obaid-ur-Rehman et al., 2004). In this study IPR was calculated at $80 \%$ relative grain yield level using equations derived from graphical plots of relative grain yields against corresponding total $\mathrm{P}$ uptake values.

External $\mathrm{P}$ requirement $(\mathrm{EPR})=$ concentration of $\mathrm{P}$ in the soil solution associated with $80 \%$ yield (Fox, 1981; Hue et al., 2000; Obaid-ur-Rehman et al., 2004).The EPR were calculated using equations derived from graphical plots of relative grain yields against corresponding soil solution $\mathrm{P}$ concentrations at crop harvest.

Relative grain yield $($ RGY $)=($ Actual grain yield $) /$ (Maximum grain yield)x 100

Analysis of variance on data on grain and total dry matter yields, nutrient uptake and physiological P use efficiency was performed using Mstat C software (Michigan State University, 1991). The means were separated using Least Significant Difference (LSD), and the total $\mathrm{P}$ uptake was regressed on grain yields (Steel and Torrie, 1980).

\section{RESULTS AND DISCUSSION}

Soils. Some of the chemical and physical properties of soils at the 4 sites are given in Table 2. The soils are predominantly sandy loam in texture. Available $\mathrm{P}$ at the sites was below critical level of $10 \mathrm{mg} \mathrm{kg}^{-1}$ (Okalebo et al., 2002). The very low soil available $\mathrm{P}$ obtained at the sites is illustrative of $\mathrm{P}$ insufficiency that is endemic in many farms in the region (Sanchez et al., 1997; Sanchez, 2002; Bunemann, 2003; Millennium Villages Project, 2005). Organic carbon in the soils was within $0.5-1.5 \%$, a range considered low (Okalebo et al., 2002). The cations Ca, Mg, and K levels were adequate at all the experimental sites (Hinga et al., 1980). Aluminum saturation levels for the soils at Ayora and Wagai sites were above $30 \%$, the critical level for toxicity on maize (Okalebo et al., 2002). It is acknowledged, with regret, that Mn content of experimental soils was not determined and yet the element, besides $\mathrm{Al}$, constitutes hindrance to plant growth in soils with $\mathrm{pH} \leq 5.5$.

Grain yields. Phosphorus application significantly increased maize grain yields at all the four sites (Table 3$)$. The check (0 kg P ha-1) and $39 \mathrm{~kg} \mathrm{P}$ ha $^{-1}$ treatments resulted in significantly $(\mathrm{p}<0.05)$ lowest and highest grain yields. Significant increase in maize grain yields due to $\mathrm{P}$ application at the 4 sites is indicative of low inherent soil $\mathrm{P}$ at these sites. These yield responses underscore the significance of fertiliser $\mathrm{P}$ use in enhancing maize yields in the study soils.

The effects of $\mathrm{P}$ application rates varied with the varieties at the sites (Table 3). Ababari compared well with $\mathrm{H} 513$ at all the sites except at Ayora. The lack of significant grain yield responses of Ababari to $\mathrm{P}$ application rates beyond $13 \mathrm{~kg} \mathrm{P} \mathrm{ha}^{-1}$ at Ayora in contrast to situations at the other sites was probably due to the high Al saturation at Ayora (Table 2). The lower grain yields of Ababari at Ayora than at 
TABLE 3. Maize grain yields (at 15\% moisture content), above ground dry matter production, and harvest index at the four sites as influenced by variety and fertiliser $P$ application

\begin{tabular}{|c|c|c|c|c|c|c|c|c|c|c|}
\hline \multirow[t]{3}{*}{ Site } & \multirow{3}{*}{$\begin{array}{l}\text { P rate, } \\
\left(\mathrm{kg} \mathrm{P} \mathrm{ha}^{-1}\right)\end{array}$} & \multicolumn{9}{|c|}{ Variety } \\
\hline & & Ababari & Oking' & H513 & Ababari & Oking' & H513 & Ababari & Oking' & $\mathrm{H} 513$ \\
\hline & & \multicolumn{3}{|c|}{ Grain yield $\left(\mathrm{kg} \mathrm{ha}^{-1}\right)$} & \multicolumn{3}{|c|}{ Total dry matter yield $\left(\mathrm{t} \mathrm{ha}^{-1}\right)$} & \multicolumn{3}{|c|}{ Harvest index } \\
\hline \multirow[t]{5}{*}{ Ayora } & 0 & 1345 & 234 & 695 & 2.83 & 1.99 & 2.13 & 0.21 & 0.11 & 0.14 \\
\hline & 13 & 2812 & 1473 & 3488 & 4.98 & 5.01 & 7.08 & 0.43 & 0.26 & 0.41 \\
\hline & 26 & 2921 & 3107 & 3885 & 6.39 & 7.12 & 7.85 & 0.42 & 0.36 & 0.46 \\
\hline & 39 & 3259 & 4072 & 5090 & 6.54 & 7.91 & 11.08 & 0.39 & 0.40 & 0.35 \\
\hline & 52 & 2783 & 3717 & 3915 & 7.60 & 7.38 & 8.79 & 0.36 & 0.40 & 0.40 \\
\hline LSD $_{0.05}$ & & & 1094 & & & 2.0 & & & 0.14 & \\
\hline \multirow[t]{5}{*}{ Wagai } & 0 & 1367 & 1546 & 3080 & 3.03 & 5.36 & 4.05 & 0.19 & 0.19 & 0.22 \\
\hline & 13 & 3940 & 3597 & 3945 & 8.02 & 8.56 & 8.79 & 0.42 & 0.34 & 0.36 \\
\hline & 26 & 5155 & 4345 & 4371 & 12.57 & 9.52 & 9.09 & 0.40 & 0.36 & 0.32 \\
\hline & 39 & 5656 & 4459 & 5478 & 12.96 & 10.39 & 10.74 & 0.40 & 0.39 & 0.42 \\
\hline & 52 & 6479 & 5219 & 5835 & 13.46 & 11.60 & 10.07 & 0.41 & 0.35 & 0.40 \\
\hline $\operatorname{LSD}_{0.05}$ & & & 1850 & & & 4.60 & & & 0.10 & \\
\hline \multirow[t]{5}{*}{ Aboke } & 0 & 1514 & 310 & 304 & 4.15 & 1.68 & 1.61 & 0.38 & 0.18 & 0.22 \\
\hline & 13 & 2567 & 1521 & 1056 & 7.57 & 5.32 & 3.53 & 0.35 & 0.23 & 0.30 \\
\hline & 26 & 2721 & 2986 & 2116 & 6.71 & 8.36 & 6.40 & 0.39 & 0.34 & 0.31 \\
\hline & 39 & 3781 & 3113 & 3185 & 9.59 & 8.56 & 7.68 & 0.38 & 0.33 & 0.37 \\
\hline & 52 & 2964 & 2223 & 2002 & 6.69 & 6.94 & 5.58 & 0.35 & 0.31 & 0.24 \\
\hline LSD $_{0.05}$ & & & 1006 & & & 3.04 & & & 0.17 & \\
\hline \multirow[t]{5}{*}{ Ukwala } & 0 & 1250 & 903 & 661 & 3.32 & 3.56 & 2.47 & 0.20 & 0.17 & 0.25 \\
\hline & 13 & 1771 & 1137 & 1810 & 3.74 & 4.77 & 2.99 & 0.19 & 0.30 & 0.30 \\
\hline & 26 & 1957 & 1817 & 2177 & 7.67 & 4.61 & 3.75 & 0.31 & 0.20 & 0.25 \\
\hline & 39 & 2732 & 2299 & 2530 & 5.15 & 3.75 & 7.34 & 0.24 & 0.17 & 0.35 \\
\hline & 52 & 1689 & 1515 & 2350 & 6.32 & 3.44 & 6.41 & 0.28 & 0.19 & 0.32 \\
\hline LSD $_{0.05}$ & & & 1106 & & & 2.91 & & & 1.10 & \\
\hline
\end{tabular}

Wagai, both sites having received similar rainfall (Table 1), is indicative of negative effect of soil $\mathrm{Al}$ saturation on Ababari. In contrast, Oking' and hybrid H513 produced significant increases in grain yields to $P$ application rates beyond $13 \mathrm{~kg} P$ ha $^{-1}$ at Ayora, Wagai, and Aboke sites (Table 3). This probably indicated that both Oking' and hybrid H513 were less sensitive to Al saturation at least to the magnitude measured at Ayora (Baligar et al., 1997).
There was significantly ( $\mathrm{p}<0.05$ ) low grain production by all the 3 varieties at Aboke and Ukwala compared to the yields at Ayora and Wagai (Table 3). There was, however, no significant interaction effect among the main treatments. Striga [Striga hermonthica (Del.) Benth.] occurrence at Aboke and Ukwala sites could be a constraining factor to maize growth and yields at the 2 sites. Low grain yields at Aboke are also attributable to comparatively low rainfall received at the site during the season (Table 1). 
Interaction effects among the main treatments were possibly subdued by high $\mathrm{Al}$ at some sites (Ayora and Wagai) and striga infestation at other sites (Aboke and Ukwala), coupled with low rainfall at other sites (Aboke).

Total dry matter yields and harvest index. Total dry matter production by the three maize varieties increased with the increasing $\mathrm{P}$ application rate at the 4 sites, in a pattern similar to that of grain production (Table 3). Higher P rate than $26 \mathrm{~kg} P$ $\mathrm{ha}^{-1}$ did not result in significantly higher total dry matter yield. There was no consistent difference in varieties with respect to total dry matter yield. Wagai site had the highest total dry matter yields by all the 3 maize varieties with the mean values of 10, 9 and 8 t ha $^{-1}$ for Ababari, Oking', and H513, respectively. Ukwala site had the lowest dry matter yields from each of the three varieties. The relatively better performance by all the varieties at Wagai site compared to other sites is attributed to a combination of favorable growth conditions, namely high rainfall (Table 1), low Al saturation (Table 2), and absence of striga weed.

Fertiliser $\mathrm{P}$ application significantly $(p<0.05)$ increased harvest index (HI) over the check in all the 3 maize varieties at the 4 sites (Table 3). However, there was no difference between the $\mathrm{P}$ rates higher than $13 \mathrm{~kg} \mathrm{P} \mathrm{ha}^{-1}$. The implication here is that $\mathrm{P}$ rates higher than $13 \mathrm{~kg} \mathrm{P} \mathrm{ha}^{-1}$ did not improve dry matter partitioning to grains under the experimental conditions. The lack of significant differences in $\mathrm{HI}$ due to $\mathrm{P}$ rates above $13 \mathrm{~kg} \mathrm{P} \mathrm{ha-1}$ was attributed to simultaneity increases in grain and total dry matter production in addition to low plasticity within the varieties in terms of dry matter partitioning to the grains within the $\mathrm{P}$ application range. At $39 \mathrm{~kg} \mathrm{P} \mathrm{ha}^{-1}$ the mean HI values for Wagai, Aboke, Ukwala, and Ayora were $0.42,0.37,0.35$, and 0.35 , respectively. The HI value for Wagai is comparable to the values reported by Sigunga et al. (2002) for H513 also grown in western Kenya. The authors applied $44 \mathrm{~kg} \mathrm{P}$ and $60 \mathrm{~kg} \mathrm{~N} \mathrm{ha}^{-1}$ to the crop grown on a Vertisol and obtained HI values ranging from 0.43 to 0.46 . The relatively lower HI values at the other sites are attributed to adverse environmental growth conditions as constituted by high $\mathrm{Al}$ (Ayora site), low rainfall (Aboke site), and heavy striga infestation (Ukwala site).
Internal $P$ requirements of maize. Phosphorus application significantly $(p<0.05)$ increased $\mathrm{P}$ uptake by the varieties at the four sites (Table 4 ). Internal $P$ requirements varied for the three maize varieties at the four sites as quadratic functions obtained from graphical plots of relative grain yields against total $\mathrm{P}$ uptake illustrated in Figure 1. The varieties had internal $P$ requirements of 7.2, 10.4, and $9.5 \mathrm{~kg} \mathrm{P} \mathrm{ha}^{-1}$ at Ayora site for Ababari, Oking', and H513, respectively while at Wagai site the internal P requirements were 16.5, 12.5, and $12.0 \mathrm{~kg} \mathrm{P} \mathrm{ha}^{-1}$ for Ababari, Oking', and H513, respectively. Variety internal $P$ requirements were 23.7, 18.2, and $18.1 \mathrm{~kg} \mathrm{P}^{-1}$ for Ababari, Oking, and H513, respectively, at Aboke site. The values at Ukwala were $6.5,4.2$, and $5.4 \mathrm{~kg} \mathrm{P} \mathrm{ha}^{-1}$ for Ababari, Oking', and H513, respectively. Internal $\mathrm{P}$ requirements for Oking' and $\mathrm{H} 513$ were similar at all the sites. Ababari exhibited higher internal $\mathrm{P}$ requirement than the other 2 varieties at all the sites except at Ayora. The internal $\mathrm{P}$ requirements varied with both maize variety and experiment site, but more with latter than the former. This is probably because the environmental factors influence, to a large extent, the sink expression of the crop. The variation in $\mathrm{P}$ uptake and internal $\mathrm{P}$ requirements of maize varieties with site (Table 4 and Fig. 1) are attributed to growth conditions as constituted by soil factors and climatic constituents, as well as biotic factors particularly striga weeds. Sites with unfavorable growth conditions like Ayora (high Al saturation) and Ukwala (heavy striga infestation) resulted in relatively low $\mathrm{P}$ uptake and showed low internal $P$ requirements. The variation of internal $P$ requirements with variety found in the current study (Fig. 1) is in conformity with the results of other workers (Duncan and Baligar, 1990; Horst et al., 1993).

Results from Wagai and Ayora sites, where similar climatic conditions prevailed (Table 1) and soils were both ferric Alisols, illustrated that even within the same soil type, differences in soil properties such as Al saturation influenced variety internal $\mathrm{P}$ requirements. Ababari and Oking', unlike hybrid H513, had higher internal P requirements at Wagai than at Ayora indicating that the two varieties responded to the differences in Al saturation at the sites. Furthermore, the magnitudes of change in internal $P$ requirements 
TABLE 4. Uptake of $P$ by maize at the 4 sites as influenced by variety and fertiliser $P$ application rates

\begin{tabular}{|c|c|c|c|c|c|}
\hline \multirow[t]{3}{*}{ Variety } & \multirow{3}{*}{$\begin{array}{c}\text { P rate } \\
\left(\mathrm{kg} \mathrm{P} \mathrm{ha}^{-1}\right)\end{array}$} & \multicolumn{4}{|c|}{ Site } \\
\hline & & Ayora & Wagai & Aboke & Ukwala \\
\hline & & 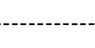 & ----- P up & ----------' & 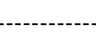 \\
\hline \multirow[t]{5}{*}{ Ababari } & 0 & 3.59 & 4.75 & 11.60 & 3.43 \\
\hline & 13 & 8.57 & 13.76 & 22.13 & 3.95 \\
\hline & 26 & 9.82 & 18.12 & 22.67 & 6.86 \\
\hline & 39 & 9.21 & 18.47 & 29.23 & 6.00 \\
\hline & 52 & 12.15 & 25.13 & 15.07 & 6.50 \\
\hline \multirow[t]{5}{*}{ Oking' } & 0 & 2.26 & 3.51 & 2.45 & 3.42 \\
\hline & 13 & 6.95 & 11.94 & 12.90 & 8.64 \\
\hline & 26 & 11.83 & 13.51 & 19.15 & 4.00 \\
\hline & 39 & 11.53 & 13.70 & 22.18 & 3.40 \\
\hline & 52 & 10.83 & 14.10 & 20.43 & 3.98 \\
\hline \multirow[t]{5}{*}{ H513 } & 0 & 2.71 & 4.25 & 4.37 & 2.76 \\
\hline & 13 & 7.69 & 12.65 & 6.90 & 6.54 \\
\hline & 26 & 8.70 & 7.46 & 16.76 & 2.81 \\
\hline & 39 & 9.51 & 14.22 & 22.06 & 9.33 \\
\hline & 52 & 16.08 & 15.98 & 21.91 & 6.93 \\
\hline LSD $_{0.05}$ & & 4.84 & 8.40 & 10.28 & 3.45 \\
\hline
\end{tabular}

for the two varieties between the two sites were $9.3 \mathrm{~kg} \mathrm{P} \mathrm{ha-1}$ for Ababari and $2.1 \mathrm{~kg} \mathrm{P} \mathrm{ha}^{-1}$ for Oking'. These changes in internal $\mathrm{P}$ requirements could be due to differences between the two varieties in terms of sensitivity to change in $\mathrm{Al}$ saturation levels. The reduction in internal $\mathrm{P}$ requirement by the two open pollinated varieties with increase in $\mathrm{Al}$ saturation levels at Ayora site could have resulted from a reduction in uptake of $\mathrm{P}$ and other essential nutrients due to negative Al saturation effects (toxicity) on the root systems, which reduced dry matter production. Reduced root volume as a result of Al toxicity has been reported to contribute to low dry matter production by $\mathrm{Al}$ sensitive varieties (Baligar et al., 1997). Reduced root zone volume reduces $P$ uptake by maize (Masoni et al., 2002). Since dry matter production is a functional component of internal $\mathrm{P}$ requirements, a reduction in its production is likely to lower the internal $\mathrm{P}$ requirements of the crop. Striga occurrence at Ukwala site could be a contributing factor to reduced total $\mathrm{P}$ uptake and variety internal $\mathrm{P}$ requirements through its negative effect on total dry matter production.

External $\mathbf{P}$ requirements of maize. High variations characterised data on soil solution $\mathrm{P}$ concentrations at crop harvesting. This is illustrated by coefficients of variations of 88.8 and $178.8 \%$, which were associated with soil solution $\mathrm{P}$ concentration data for Ayora and Aboke sites, respectively. Phosphorus application rates at the sites did not significantly influence $(\mathrm{P}>0.5)$ soil solution $\mathrm{P}$ concentrations at crop harvesting possibly as a result of masking effect of high coefficient of variation in the data. High variations in the data could in part be attributed to row application of fertiliser $P$ and in part to effects of hand weeding that could have lead to uneven spatial redistribution of the rowapplied fertiliser $\mathrm{P}$ within the plots. The uneven redistribution of fertiliser $\mathrm{P}$ coupled with usual low within-soil mobility of P could have led to low equilibration of soil solution $\mathrm{P}$ within plant rhizosphere and soil sampling area. This could 

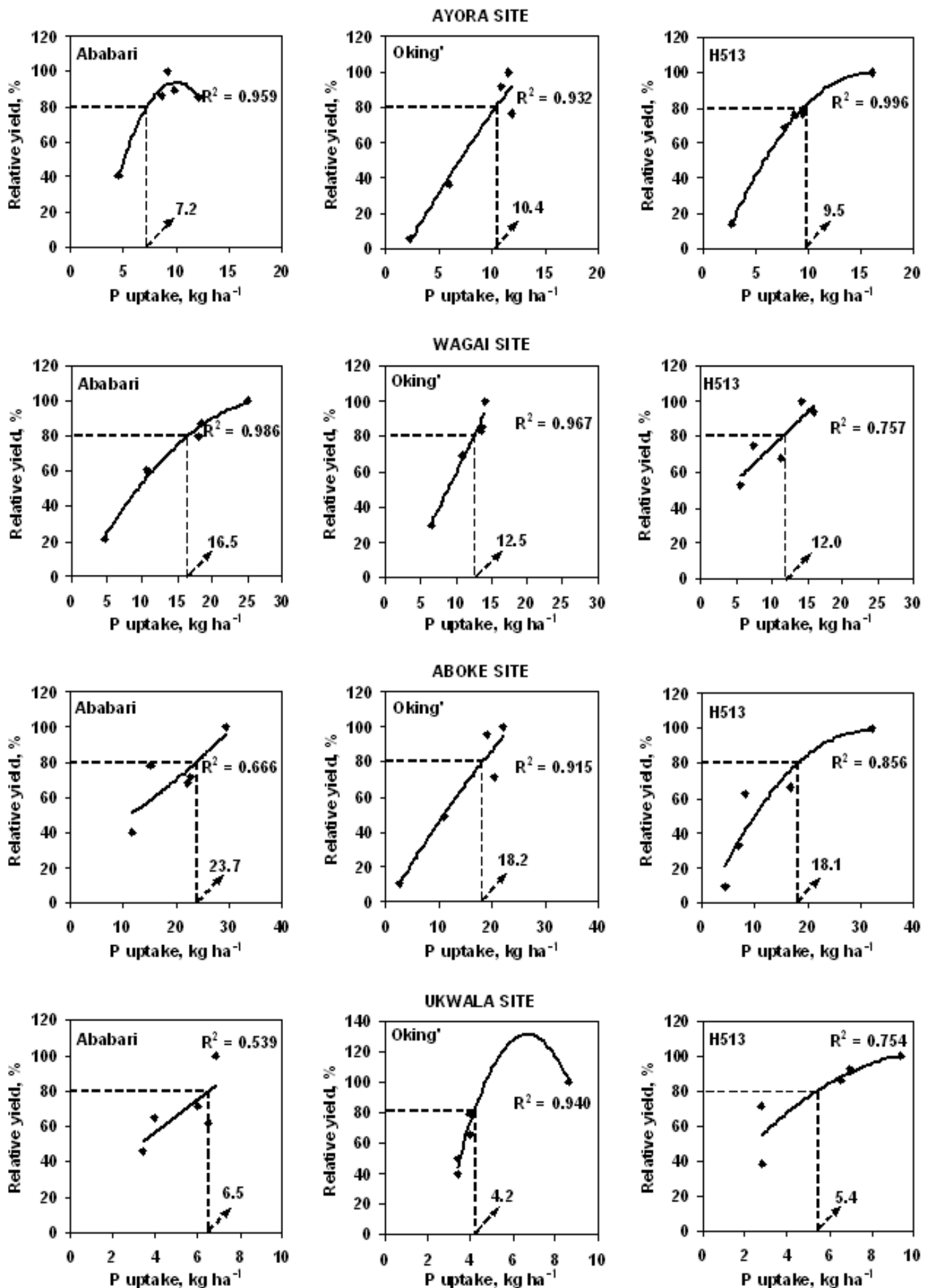

Figure 1. Relationships between maize variety, and total $P$ uptake, relative grain yield, variety. internal $P$ requirements at the experimental sites. 
have rendered the soil sampling procedure and timing of the soil sampling to be inappropriate. Consequently, external $\mathrm{P}$ requirements by the varieties could not be reliably determined using the soil solution $\mathrm{P}$ concentration data obtained from the sites. We suggest that broadcast application of $\mathrm{P}$ would enhance even distribution of $\mathrm{P}$ and lower soil $\mathrm{P}$ variability. This would possibly be suitable for soil sampling for the determination of soil solution P plot by plot.

Phosphorus physiological efficiency. In respect of each of the three varieties, the check (plots that did not receive fertiliser $P$ ) had significantly $(p<0.05)$ lower phosphorus physiological efficiency (PPE) than plots that received $P$ applications. This was consistent across the 4 sites (Table 5). There was no significant difference in PPE due to $\mathrm{P}$ application rates 13 to $52 \mathrm{~kg} \mathrm{ha}^{-1}$ across the sites in the case of Ababari and Oking'. For H513, however, there were differences though inconsistent. There were no differences between the varieties within a site, except at Ayora, where H513 had significantly ( $p$ $<0.05$ ) higher PPE than the other varieties. The PPE at $80 \%$ relative grain yields at Ayora site were 241, 251, and $390 \mathrm{~kg}$ grain $\mathrm{kg}^{-1} \mathrm{P}$ for Ababari, Oking', and H513, respectively. At Wagai site, PPE values were 314,277 , and 340 kg grain dm kg${ }^{1} \mathrm{P}$ for Ababari, Oking', and H513, respectively. The values at Aboke site were 111, 145, and 127 $\mathrm{kg}$ grain $\mathrm{dm} \mathrm{kg}^{-1} \mathrm{P}$ for Ababari, Oking', and H513, respectively. At Ukwala site, the values were 245, 231, and $245 \mathrm{~kg}$ grain $\mathrm{dm} \mathrm{kg}^{-1} \mathrm{P}$ for Ababari, Oking', and H513, respectively.

The significantly higher PPE in the plots that received fertiliser $\mathrm{P}$ over the check was possibly due to a number of interacting factors. To a Pdeficient soil , as is the case with the experimental sites in the current experiments, $\mathrm{P}$ application is likely to improve root system and enhance uptake of $\mathrm{P}$, in addition to other essential plant nutrient elements as well as moisture. Increased nutrient and water uptake inevitably results in increased

TABLE 5. Phosphorus physiological efficiency (PPE) of maize variety as affected by variety and fertilizer $P$ application rates at the 4 sites $(n=3)$

\begin{tabular}{|c|c|c|c|c|c|}
\hline \multirow[t]{3}{*}{ Variety } & \multirow{3}{*}{$\begin{array}{c}\text { P rate } \\
\left(\mathrm{kg} \mathrm{P} \mathrm{ha}^{-1}\right)\end{array}$} & \multicolumn{4}{|c|}{ Site } \\
\hline & & Ayora & Wagai & Aboke & Ukwala \\
\hline & & --------- & $E(\mathrm{~kg}$ gra & ake) ----- & -------- \\
\hline \multirow[t]{5}{*}{ Ababari } & 0 & 123 & 159 & 120 & 175 \\
\hline & 13 & 247 & 312 & 164 & 197 \\
\hline & 26 & 271 & 291 & 112 & 351 \\
\hline & 39 & 290 & 280 & 125 & 192 \\
\hline & 52 & 226 & 218 & 160 & 246 \\
\hline \multirow[t]{5}{*}{ Oking' } & 0 & 106 & 150 & 109 & 174 \\
\hline & 13 & 227 & 265 & 141 & 256 \\
\hline & 26 & 225 & 264 & 175 & 223 \\
\hline & 39 & 269 & 299 & 126 & 176 \\
\hline & 52 & 274 & 305 & 112 & 153 \\
\hline \multirow[t]{5}{*}{ H513 } & 0 & 176 & 228 & 80 & 274 \\
\hline & 13 & 369 & 255 & 157 & 249 \\
\hline & 26 & 413 & 387 & 116 & 187 \\
\hline & 39 & 326 & 315 & 89 & 267 \\
\hline & 52 & 279 & 255 & 161 & 291 \\
\hline LSD $_{0.05}$ & & 118.0 & 109.8 & 86.1 & 130.9 \\
\hline
\end{tabular}


total dry matter and grain yields (Table 3). It was reported (Colomb et al., 2000; Pellerin et al., 2000) that the increase in dry matter production following $\mathrm{P}$ application is a result of improved root system, increased leaf area index and its subsequent effect on photosynthetically active radiation absorption and carbohydrate nutrition of plants. The lack of significant difference in PPE by Ababari and Oking' at 13-52 kg ha-1 $\mathrm{P}$ application range indicates low variation in $\mathrm{P}$ utilisation within this range possibly because of genetic effects. In comparison to H513, low PPE by Ababari and Oking' at Ayora site could be attributed to low efficiency in grain dry matter production relative to $\mathrm{P}$ uptake possibly due to effects of high \% Al saturation at the site.

\section{CONCLUSIONS AND RECOMMENDATION}

Open pollinated Ababari is as good as hybrid H513 in terms of grain yield, P uptake and phosphorus physiological efficiency. Internal $\mathrm{P}$ requirements depends on both maize variety and environment, but more on environment than variety. Harsh environmental factors, namely high \% $\mathrm{Al}$, striga, and low rainfall reduce the response of the maize varieties to $\mathrm{P}$ application. Row application of $\mathrm{P}$ results in high infield spatial variation in soil solution $\mathrm{P}$ that made crop external $P$ requirement determination unreliable.

We recommend Ababari for the resource poor farmers since its performance is virtually as good as the commercially recommended hybrid H513 for the study area in light of the fact that farmers do not need to purchase the high cost hybrid H513 seed.

\section{ACKNOWLEDGEMENT}

The authors acknowledge the research grant from Rockefeller Foundation (RF 99020 \#215).

\section{REFERENCES}

Anderson, J.M. and Ingram, J.S.I. 1993. Tropical Soil Biology and Fertility: A Handbook of Methods. $2^{\text {nd }}$ Edn. C.A.B. International, Wallingford. 221pp.

Baligar, V.C., Pitta, G.V.E., Gama, E.E.G., Schaffert, R.E., Bahia Filho, A.F de C., and Clark, R.B.
1997. Soil acidity effects on nutrient use efficiency in exotic maize varieties. Plant and Soil 192: 9-13.

Bunemann, E.K. 2003. Phosphorus dynamics in a Ferralsol under maize-fallow rotations: The role of the soil microbial biomass. PhD Thesis, Swiss Federal Institute of Technology Zurich. 162 pp.

Colomb, B., Kiniry, J R., and Debaeke, P. 2000. Effect of soil phosphorus on leaf development and senescence dynamics of field-grown maize. Agronomy Journal 92: 428-435.

Corbett, J.D., Muchugu, E.I., Bush, B.R.,Collis, S.N., and Jeske, R.Q. 2001. Kenya ACT database 3.0. BREC Report Number 01 - 14. Texas A \& M Univ. System, Texas Agric. Expt. Sta., Blackland Res. and Ext. Centre, Temple, Texas.

Duncan, R.R. and Baligar, V.C. 1990. Genetics, breeding, and physiological mechanisms of nutrient uptake and use efficiency: An overview. In: Crops as Enhancers of Nutrient Use. Baligar V.C. and Duncan, R.R. (Eds.), pp. 3-35. Academic Press, London.

FAO. 2004. (Food and Agriculture Organization). Gateway to Land and Water Information Kenya National Report. http://www.fao.org/ ag/agl/swlwpnr/reports/y sf/z ke/ke.htm

FAO-UNESCO. 1997. FAO-UNESCO soil map of the world. Revised legend with corrections and updates. Technical Paper 20, ISRIC, Wageningen.

Fox, R.L. 1981. External phosphorus requirements of crops. Agronomy Journal 73: 223-239.

Gee, G.W. and Bauder, J.W. 1986. Particle size analysis. In: Methods of soil Analysis, Part 1. $2^{\text {nd }}$ Edn. Agron. Monog. 9. Klute, A. (Ed.), pp. 383-411. ASA and SSSA, Madison, WI.

Hedley, M.J., Mortvedt, J.J., Bolan, N.S., and Syers, J. K. 1995. Phosphorus fertility management in agroecosystems. In: Phosphorus in the Global Environment. Tiessen, H. (Ed.). Ch. 5. John Wiley \& Sons, NY.

Hinga, G., Muchena, F.N., and. Njihia, C.M. 1980. Physical and chemical methods of soil analysis. National Agricultural Research Laboratories, Nairobi, Kenya.

Horst, W.J., Abdou, M., and Wiesler, F.1993. Genotypic differences in phosphorus 
efficiency of wheat. In: Plant nutrition - from genetic engineering to field practice. Proceedings of the Twelfth International Plant Nutrition Colloquium, Barrow, N.J. (Ed.), pp. 367-370. Kluwer, Amsterdam.

Hue, N.V., Ikawa, H., and Huang, X. 2000. Predicting soil phosphorus requirements. In: Plant Nutrient Management in Hawaii's Soils, Approaches for Tropical and Subtropical Agriculture. Silva, J.A. and Uchida, R. (Eds.), pp. 95-99. College of Tropical Agriculture and Human Resources, University of Hawaii at Manoa.

Jaetzold, R. and Schmidt, H. 1982. Farm management handbook of Kenya- Natural conditions and farm management information, Volume II/A, Western Kenya. Ministry of Agriculture, Nairobi, Kenya.

Keerthisinghe, G., Chalk, P., and Zapata, F. 2003. Plant nutrition: challenges and tasks ahead. IFA-FAO Agriculture Conference on Global Food Security and the Role of Sustainable Fertilisation. 26-28 March, 2003, Rome, Italy. http://www.fertiliser.org/ifa/publicat/PDF/ 2003 rome keerthisinghe.pdf

Machado, C.T. Almeida, D.L., and Machado, A.T. 1999. Variability among maize varieties to phosphorus use efficiency. Bragantia 958(1): 109-124.

Masoni, A., Mariotti, M., and Ercoli, L. 2002. Maize growth and nutrient uptake as affected by root zone volume. Italian Journal of Agronomy 1, 2: 95-102.

Michigan State University. 1991. MSTAT - C: A Software Program for the Design, Management, and Analysis of Agronomic Research Experiments. Michigan State University, Ann Arbor, MI

Millennium Villages Project. 2005. Millennium research villages 2004-2005 Annual Report. Tropical Agriculture Program,The Earth Institute at Columbia University. www.earthinstitute.columbia.edu/mvp/ documents/MVP_Annual_Report_05_000. pdf.

Nelson, D.W. and Sommers, L.E. 1982. Total carbon, organic carbon and organic matter. In: Methods of Soil Analysis. Part 2: Chemical and Microbiological Properties.
A.L. Page (Ed.), pp. 539-594. ASA, SSSA Inc. Madison, Wisconsin, USA.

Nielsen, N.E. and Barber, S.A. 1978. Differences between varieties of corn in kinetics of phosphorus uptake. Agronomy Journal 70(5): 695-698.

Njui, N.A. and Musandu, A.A.O. 1999. Response of maize to phosphorus fertilisation at selected sites in western Kenya. African Crop Science Journal 7(4): 397-406.

Nyandat, N.N. 1981. The primary minerals in some Kenya's topsoils and their significance to inherent soil fertility. East African Agricultural and Forestry Journal 46 (3): 7176.

Obaid-ur-Rehman, Ranjha, A.M., Gill, M.A., and Mehdi, S.M. 2004. Phosphorus requirement of wheat using modified Freundlich model in Rasulpur soil series. Pakistan Journal of Agricultural Science 41(1-2): 39-46.

Oenema, O. and Pietrzak, S. 2002. Nutrient management in food production: Achieving agronomic and environmental targets. Ambio 31:159-168.

Okalebo, J.R., Gathua, K.W., and Woomer, P.L. 2002. Laboratory methods of soil and plant analysis: A working manual. $2^{\text {nd }}$ Edn. TSBFCIAT and SACRED Africa, Nairobi, Kenya. $128 \mathrm{pp}$.

Pellerin, S., Mollier, A., and Plénet, D. 2000. Phosphorus deficiency affects the rate of emergence and number of maize adventitious nodal roots. Agronomy Journal 92: 690-697.

Sanchez, P.A. 2002. Soil fertility and hunger in Africa. Science 295: 2019-2020.

Sanchez, P.A., Shephard, K.D., Soule, M.J., Place, F.M., Buresh, R.J., Izac, A.N., Mokwunye, A.U., Kwesiga, F.R., Ndiritu, C.G., and Woomer, P.L. 1997. Soil fertility replenishment in Africa: An investment in natural resource capital. In: Replenishing soil fertility in Africa, SSSA Special Publication Number 51. Buresh, R.J., Sanchez, P.A., and Calhoun, F. (Eds.), pp. 1-46. SSSA, ASA. Madison, Wisconsin, USA.

Sigunga, D.O., Janssen, B.H., and Oenema, O. 2002. Effects of improved drainage and nitrogen source on yields, nutrient uptake, and utilization efficiencies by maize (Zea mays 
L.) on Vertisols in sub-humid environments. Nutrient Cycling in Agroecosystems 62: 263275.

Smaling, E.M.A., Nandwa, S.M., and Janssen, B.H. 1997. Soil fertility in Africa is at stake. In: Replenishing soil fertility in Africa, SSSA Special Publication Number 51. Buresh, R.J., Sanchez, P.A., and Calhoun, F. (Eds.), pp. 4761. SSSA, ASA. Madison, Wisconsin, USA. Van der Eijk, 1997. Phosphate Fixation in Kenyan Soils. PhD Thesis, Wageningen Agricultural
University, Wageningen, The Netherlands. $162 \mathrm{pp}$.

Van Lierop, W. 1990. Soil pH and lime requirement determination. In: Soil testing and plant analysis. Westerman, R.L (Ed.), pp. 76-120. SSSA, Madison, Wisconsin, USA.

Walker, W.M. and Raines, G.A. 1988. Effect of corn cultivar, phosphorus and potassium on yield and chemical composition. Journal of Plant Nutrition 112(12): 1715-1726. 